medRxiv preprint doi: https://doi.org/10.1101/2021.04.13.21255416; this version posted April 20, 2021. The copyright holder for this preprint (which was not certified by peer review) is the author/funder, who has granted medRxiv a license to display the preprint in perpetuity.

It is made available under a CC-BY 4.0 International license .

Iron and neuromelanin in PD using 7T MRI - P a g e | 1

\title{
Substantia nigra ferric overload and neuromelanin loss in Parkinson's disease measured with 7T MRI
}

Catarina Rua ${ }^{a, b}$, Claire O'Callaghan ${ }^{c, d}$, Rong Ye ${ }^{b}$, Frank H. Hezemans ${ }^{b, f}$, Luca Passamonti, ${ }^{b, e}$, P Simon Jones ${ }^{b}$, Guy B Williams ${ }^{a}$, Christopher T Rodgers ${ }^{a}$, James B Rowe ${ }^{b, f}$

\section{Affiliations:}

a) Wolfson Brain Imaging Centre, Department of Clinical Neurosciences, University of Cambridge, Cambridge, UK

b) Department of Clinical Neurosciences, University of Cambridge, Cambridge, UK

c) Department of Psychiatry, University of Cambridge, UK

d) Brain and Mind Centre and School of Medical Sciences, Faculty of Medicine and Health, University of Sydney, Australia

e) Istituto di Bioimmagini e Fisiologia Molecolare (IBFM), Consiglio Nazionale delle Ricerche (CNR), Milano, Italia

f) MRC Cognition and Brain Sciences Unit, University of Cambridge, Cambridge, UK

\section{Corresponding author:}

Name: Catarina Rua

Address: The Wolfson Brain Imaging Centre, Box 65, Cambridge Biomedical Campus, Cambridge, CB2 0QQ, UK Telephone: +447709 774939

e-mail address: cr439@cam.ac.uk

\section{Keywords:}

7T MRI; Parkinson's disease; Substantia Nigra; Iron; Neuromelanin. 
medRxiv preprint doi: https://doi.org/10.1101/2021.04.13.21255416; this version posted April 20, 2021. The copyright holder for this preprint (which was not certified by peer review) is the author/funder, who has granted medRxiv a license to display the preprint in perpetuity.

It is made available under a CC-BY 4.0 International license .

Iron and neuromelanin in PD using 7T MRI - P a g e $\mid 2$

\section{Abstract:}

Background: Vulnerability of the substantia nigra dopaminergic neurons in Parkinson's disease is associated with ferric overload, leading to neurodegeneration with cognitive and motor decline. Here, we quantify iron and neuromelanin-related markers in vivo using ultrahigh field 7-Tesla MRI, and examine the clinical correlates of these imaging assessments.

Methods: Twenty-five people with mild-to-moderate Parkinson's disease and twenty-six healthy controls underwent high-resolution imaging at 7-Tesla with a $\mathrm{T}_{2}{ }^{*}$-weighted sequence (measuring susceptibility- $\chi$ and $\mathrm{R}_{2}{ }^{*}$, sensitive to iron) and a magnetization transfer-weighted sequence (MT-w, sensitive to neuromelanin). From an independent control group ( $N=29)$, we created study-specific regions-of-interest for five neuromelanin- and/or iron-rich subregions within the substantia nigra. Mean $\mathrm{R}_{2}{ }^{*}$, susceptibility- $\chi$ and their ratio, as well as the MT-w contrast-to-noise ratio (MT-CNR) were extracted from these regions and compared between groups. We then tested the relationships between these imaging metrics and clinical severity.

Results: People with Parkinson's disease showed a significant $\sim 50 \%$ reduction in MT-CNR compared to healthy controls. They also showed a 1.2-fold increase in ferric iron loading (elevation of the $\Delta R_{2}^{*} / \Delta \chi$ ratio from $0.19 \pm 0.058 \mathrm{~ms} / \mathrm{ppm}$ to $0.22 \pm 0.059 \mathrm{~ms} / \mathrm{ppm}$ ) in an area of the substantia nigra identified as having both high neuromelanin and susceptibility MRI signal in healthy controls. In this region, the ferric-to-ferrous iron loading was associated with disease duration $\left(\beta=0.0072, \mathrm{p}_{\mathrm{FDR}}=0.048\right)$ and cognitive impairment $\left(\beta=-0.0115, \mathrm{p}_{\mathrm{FDR}}=0.048\right)$.

Conclusions: $\mathrm{T}_{2}{ }^{*}$-weighted and MT-weighted high-resolution 7T imaging markers identified neurochemical consequences of Parkinson's disease, in overlapping but not-identical regions. These changes correlated with non-motor symptoms. 
medRxiv preprint doi: https://doi.org/10.1101/2021.04.13.21255416; this version posted April 20, 2021. The copyright holder for this preprint (which was not certified by peer review) is the author/funder, who has granted medRxiv a license to display the preprint in perpetuity. It is made available under a CC-BY 4.0 International license.

Iron and neuromelanin in PD using 7T MRI - P a g e $\mid 3$

\section{Introduction}

Iron accumulation and loss of pigmented neuromelanin cells in the substantia nigra are key parts of the complex neuropathology of Parkinson's disease (1-6). While iron is essential for normal brain homeostasis, it can become toxic by the generation of free radicals promoted by redox reactions, converting ferrous $\mathrm{Fe}^{2+}$ to the ferric $\mathrm{Fe}^{3+}$ form (7). In Parkinson's disease, iron overload and increased oxygen free radical formation induce lipid peroxidation of cell membranes (8), promoting dopaminergic neurodegeneration (9). In contrast, neuromelanin can provide a neuroprotective pathway by chelating iron and hence preventing damage by $\mathrm{Fe}^{3+}(10,11)$. However, in Parkinson's disease, the buffering capacity of neuromelanin may be exceeded, leading to neurotoxicity, oxidative stress, neuroinflammation, and ultimately loss of neurons $(10,12)$.

These pathological features in the substantia nigra of patients with Parkinson's disease have been extensively confirmed in post mortem studies $(1,2,4,6,13)$. However, characterising these changes and distinguishing different types of iron in vivo remains a challenge. Recently, specialised MRI sequences have been developed to characterise tissue iron and changes in neuromelanin content. With sufficient resolution and sensitivity, these could potentially be used to identify functionally distinct sub-regions of the substantia nigra. The ventral portion of the substantia nigra, known as the substantia nigra pars reticulata (SNr), has high concentration of iron in healthy subjects. The dorsal portion, known as the substantia nigra pars compacta (SNpc), is rich in neuromelanin, the pigmented by-product of dopamine and noradrenaline metabolism $(11,14)$.

The dopaminergic-rich SNpc can be imaged in vivo using a neuromelanin-sensitive "magnetisation-transfer weighted" (MT-w) MRI sequence (15-17). The MT-w signal intensity correlates with the location and density of the neuromelanin content in older adults (18). Alternative sequences have been used to observe changes in iron in the healthy brain and in disease $(19,20)$ by measuring the $T_{2}{ }^{*}$ transverse relaxation time (or its inverse rate, $R_{2}{ }^{*}$ ) or the local tissue magnetic susceptibly $\chi$ using quantitative susceptibility mapping (QSM) (2123). Susceptibility weighted imaging (SWI) uses post-processing of $T_{2}{ }^{*}-w$ images, with the magnitude and filtered phase information providing image contrast from iron storage (24). SWI has been shown to provide unique contrast to identify the appearance of the nigrossome- 
medRxiv preprint doi: https://doi.org/10.1101/2021.04.13.21255416; this version posted April 20, 2021. The copyright holder for this preprint (which was not certified by peer review) is the author/funder, who has granted medRxiv a license to display the preprint in perpetuity.

It is made available under a CC-BY 4.0 International license .

Iron and neuromelanin in PD using 7T MRI - P a g e $\mid 4$

62

63

64

65

66

67

68

69

70

1 (N1-sign) in healthy controls, and its loss in patients with Parkinson's disease (24).

Susceptibility imaging is sensitive to any molecule that generates an MR phase shift. In contrast to SWI, both QSM and $\mathrm{R}_{2}{ }^{*}$ provide quantitative measures of susceptibility effects. However, they are unable on their own to differentiate the sources of susceptibility, and therefore an adjunctive method is required. One approach is to capitalise on the fact that ferrous and ferric irons show differences in relaxivity per unit concentration (25), which can be estimated from the $R_{2}{ }^{*}$-to- $\chi$ ratio. We therefore take the $R_{2}{ }^{*}$-to- $\chi$ ratio as a proxy of ferric vs. ferrous loading, and use this ratio as a biomarker for iron accumulation in Parkinson's disease.

In this study, we used high resolution dedicated MRI sequences for in vivo imaging of neuromelanin with high resolution $\left(0.08 \mathrm{~mm}^{3}\right)$ and iron $\left(0.34 \mathrm{~mm}^{3}\right)$ using ultra-high field 7T, based on magnetisation transfer (26) and multi-echo $\mathrm{T}_{2}{ }^{*}$, respectively, with nigral regions of interest derived from an independent cohort of age-matched healthy controls (27). The contrast-to-noise ratio (CNR) of the MT signal was interpreted as a measure of neuromelanin content, whereas $\chi$ and $R_{2}{ }^{*}$ were used to quantify iron in the tissue. We investigated (1) the molecular changes of neuromelanin and iron in sub-regions of the substantia nigra in Parkinson's disease compared to healthy controls, and (2) the association between imaging markers and cognitive and motor functions in the patient group. We hypothesised that people with Parkinson's disease would show decreased MT signal contrast and increased $\chi$ and $R_{2}$ * in the SNpc. Since ferric iron demonstrates higher susceptibility and $\mathrm{R}_{2} *$ values than ferrous iron at the same concentration in tissue $(25,28)$ we also expected an increase of the $R_{2}{ }^{*}$-to- $\chi$ ratio in the SNpc.

\section{Methods}

\subsection{Participants}

Twenty-six healthy controls (HC, 15 male, age $65 \pm 5$ years) and twenty-five participants with Parkinson's disease (PD, 18 male, age $67 \pm 7$ years) were recruited via the University of Cambridge Parkinson's disease research clinic and the Parkinson's UK volunteer network. The study was approved by the Cambridge Research Ethics Committee (16/EE/0084; $10 /$ H0308/34) and all participants provided written informed consent in accordance with the 
medRxiv preprint doi: https://doi.org/10.1101/2021.04.13.21255416; this version posted April 20, 2021. The copyright holder for this preprint (which was not certified by peer review) is the author/funder, who has granted medRxiv a license to display the preprint in perpetuity.

It is made available under a CC-BY 4.0 International license .

Iron and neuromelanin in PD using 7T MRI - P a g e $\mid 5$

93 Declaration of Helsinki. Patients met the United Kingdom Parkinson's Disease Society Brain

94 Bank criteria and did not have dementia, based on clinical impression and mini-mental state

95 examination score (MMSE) >26/30 (29) (Table 1). They were Hoehn and Yahr stage 1.5-3, with

96 no contraindications to 7T MRI. None had current impulse control disorders, based on clinical

97 impression and the Questionnaire for Impulsive-Compulsive Disorders in Parkinson's Disease

98 (QUIP-Current Short) screening tool (30). Levodopa equivalent daily dose (LEDD) scores were

99 calculated (31) and patients were scanned on their regular medications. Control participants

100 were matched for age, sex and education, and were screened for a history of other

101 neurological or psychiatric disorders, current psychoactive medications, and

102 contraindications to 7T MRI. Two control participants were excluded due to abnormal

103 incidental findings on their $\mathrm{T}_{1}$-w structural images.

104

\begin{tabular}{|llll|}
\hline Group Study Clinical Scores & HC $(\mathbf{n}=\mathbf{2 4})$ & PD $(\mathbf{n}=\mathbf{2 5})$ & $\boldsymbol{p}$-value (HC vs. PD) \\
\hline Sex (male:female) & $13: 11$ & $18: 7$ & .09 \\
Age (years) & $66 \pm 6$ & $67 \pm 7$ & .30 \\
Education & $14.8 \pm 3.1$ & $14.1 \pm 2.3$ & .20 \\
Disease Duration (years) & - & $5 \pm 3$ & - \\
LEDD (mg/day) & - & $644.3 \pm 499.36$ & - \\
MMSE & $29.8 \pm 0.5$ & $29.5 \pm 0.7$ & .18 \\
MoCA & $28.6 \pm 1.4$ & $28.0 \pm 1.9$ & .20 \\
AS-Self-Total & $10.4 \pm 5.2$ & $12.4 \pm 5.4$ & .18 \\
UPDRS III & - & $28.4 \pm 12.0$ & - \\
BIS total & $55.7 \pm 9.6$ & $58.2 \pm 10.3$ & .39 \\
HADS anxiety & $4.3 \pm 3.5$ & $5.0 \pm 3.2$ & .44 \\
HADS depression & $2.8 \pm 2.8$ & $4.2 \pm 2.7$ & .08 \\
\hline
\end{tabular}

105

106

107

108

109

110

111

112

Table 1: Average \pm standard-deviation values for the demographics and clinical assessments of the healthy controls (HC) and patients with Parkinson's disease (PD). Group differences in sex were tested using the chi-squared test. For all other group comparisons, a two-tailed two-sample t-test was used. P-values uncorrected for multiple comparisons. Abbreviations: AS - Apathy Scale; BIS Barratt Impulsiveness Scale; HADS - Hospital Anxiety and Depression scale; MMSE - mini-mental state examination score; MoCA - Montreal cognitive assessment; UPDRS - Unified Parkinson's Disease Rating Scale; LEDD - Levodopa equivalent daily dose. 
medRxiv preprint doi: https://doi.org/10.1101/2021.04.13.21255416; this version posted April 20, 2021. The copyright holder for this preprint (which was not certified by peer review) is the author/funder, who has granted medRxiv a license to display the preprint in perpetuity. It is made available under a CC-BY 4.0 International license .

Iron and neuromelanin in PD using 7T MRI - P a g e $\mid 6$

113

114 Patients were assessed using the motor component of the Movement Disorder Society

115 Unified Parkinson's Disease Rating Scale (MDS-UPDRS-III; (32)), and both patients and healthy

116 controls underwent cognitive screening with the mini-mental state examination (MMSE;

117 (33)), Montreal cognitive assessment (MoCA; (34)). Self-rated questionnaires were used to

118 assess anxiety and depression (Hospital Anxiety and Depression Scale; HADS (35)), impulsivity

119 (Barratt Impulsiveness Scale; BIS-11 (36)) and apathy (Apathy Scale; (37)).

120 To create a template and select regions-of-interest, an independent sample of 30 additional

121 age-, sex- and education-matched healthy controls ( $\mathrm{HCi}, 17$ male, age $67 \pm 8$ years) was

122 collected as part of the same study protocol. One participant was excluded because of

123 excessive movement during scanning, resulting in 29 healthy controls in the HCi group.

\subsection{MRI acquisition}

126

MR imaging was acquired on a 7T Magnetom Terra scanner (Siemens, Erlangen, Germany) equipped with a 32-channel receive and circularly polarized single-channel transmit head coil (Nova Medical, Wilmington, USA). For iron imaging, 3D multi-echo, $0.7 \mathrm{~mm}$ isotropic $\mathrm{T}_{2}{ }^{*}$ weighted images were acquired transversely for $\mathrm{QSM}, \mathrm{R}_{2}{ }^{*}$ mapping and SWI:

$131 \mathrm{TE} 1 / \mathrm{TR}=4.68 / 27 \mathrm{~ms} ; 6$ echoes, echo-spacing=3.24ms, FA=15우 $\mathrm{BW}=430 \mathrm{~Hz} / \mathrm{px}$; acceleration-

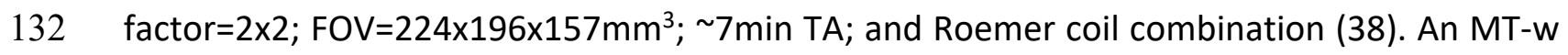

133 turbo flash sequence was used for neuromelanin imaging as described in $(26,27)$. Briefly, a

134 train of 20 RF-pulses at $6.72 \mathrm{ppm}$ off-resonance preceded a Turbo-FLASH readout:

$135 \mathrm{TE} / \mathrm{TR}=3.44 / 1251 \mathrm{~ms}$, flip-angle $=8$ o,$\quad$ voxel-size $=0.4 \times 0.4 \times 0.5 \mathrm{~mm}^{3}, \quad B W=300 \mathrm{~Hz} / \mathrm{px}$, no

136 acceleration, slices=112, 14.3\%-oversampling, $\sim 7 \min$ TA. The MT-preparation pulses were

137 calibrated to 420 FA at the middle of the pons. Two MT sequence repeats (MT-on) were

138 acquired on the $\mathrm{HC}$ and PD groups and an additional MT-on repeat was acquired in the $\mathrm{HCi}$

139 group; a repeat without off-resonance pulses was also acquired in all three groups (MT-off).

140 For anatomical co-registration, $0.7 \mathrm{~mm}$ isotropic MP2RAGE images were acquired as 141 described in (39). 
medRxiv preprint doi: https://doi.org/10.1101/2021.04.13.21255416; this version posted April 20, 2021. The copyright holder for this preprint (which was not certified by peer review) is the author/funder, who has granted medRxiv a license to display the preprint in perpetuity. It is made available under a CC-BY 4.0 International license .

Iron and neuromelanin in PD using 7T MRI - P a g e 17

\subsection{Data pre-processing}

In-house MATLAB scripts (R2018b, The MathWorks, Massachusetts, United States) together with ANTs v2.2.0 and FSL v5.0.10 were used for image pre-processing (processing scripts available upon request). QSM maps were estimated from the $T_{2}{ }^{*}-w$ scans using the multiscale dipole inversion algorithm in QSMbox (40) with the pipeline described in (23) but with the regularization parameter set to $10^{3.3}$. $\mathrm{R}_{2}$ * was estimated with the ARLO algorithm (41). To detect the relaxivity effects of ferrous $\left(\mathrm{Fe}^{2+}\right)$ and ferric $\left(\mathrm{Fe}^{3+}\right)$ components $(25)$, the $\Delta R_{2}^{*} / \Delta \chi$ ratio was measured in each voxel $i,\left(\frac{\Delta R_{2}^{*}}{\Delta \chi}\right)_{i}=\frac{R_{2 i}^{*}-R_{2_{w b}}^{*}}{\Delta \chi_{i}}$, by the ratio of the normalised $\mathrm{R}_{2} *$ maps (referenced to the whole brain $\mathrm{R}_{2}$ * value $\left(R_{2}^{*}{ }_{w b}\right)$ ) and the $\Delta \chi$ measured by QSM (MSDI QSMprocessing references $\chi$ to the whole brain $\chi$ value).

To calculate SWI maps, for each echo the raw phase was filtered with a homodyne high-pass filter (filter strength: 6.2\%). All echoes were then temporally fitted, and a normalized phase mask, $\varphi_{M}$, was generated according to equation 2 of (42) under the assumption that the phase of interest is negative. SWI maps were computed by multiplying the $\mathrm{T}_{2}{ }^{*}$-map with the fourth power of the normalized phase mask $\left(S W I=T_{2}^{*} \times \varphi_{M}{ }^{4}\right)$.

All MT scans (MT-on and MT-off) were pre-processed as previously described (27). Briefly, data was first bias field corrected. Then the MT-on images (2 repeats for $\mathrm{HC}$ and 3 repeats for $\mathrm{HCi}$ groups) were combined with the customised antsMultivariateTemplateContruction2 function setting the Laplacian sharpening off in the averaging step.

The $T_{1}-w$ MP2RAGE image was generated offline from the raw magnitude and phase of the two inversion times (43). Then, were bias-field corrected with ANTs and segmented with SPM12 (v7219) and skull-stripped.

\subsection{Analysis of independent control dataset}

$A T_{1}-\mathrm{w}$ driven, cross-modality co-registration pipeline was built to warp the MT and the QSM data from the HCi group into the isotropic $0.5 \mathrm{~mm}$ ICBM152 $\mathrm{T}_{1}-\mathrm{W}$ asymmetric brain template (44) (Figure 1). On a within-subject level, the $T_{1}-w$ images were first independently registered to the combined MT-on image (rigid transform, via the MT-off image (27)), and to the first echo of the $\mathrm{T}_{2}{ }^{*}$-w scan (rigid transform using the cross-correlation metric with weight 1 and window radius $4 \mathrm{~mm}$ ). A $T_{1}-\mathrm{w}$ structural template was created from the individual $T_{1}-\mathrm{w}$ data using a three step registration process: 1) rigid, 2) affine, and 3) hierarchical nonlinear 
medRxiv preprint doi: https://doi.org/10.1101/2021.04.13.21255416; this version posted April 20, 2021. The copyright holder for this preprint (which was not certified by peer review) is the author/funder, who has granted medRxiv a license to display the preprint in perpetuity.

It is made available under a CC-BY 4.0 International license.

Iron and neuromelanin in PD using 7T MRI - P a g e $\mid 8$

176

177

178

179

180

181

182

183

diffeomorphic registration with greedy symmetric normalisation (SyN) algorithm (45) at 5 resolution levels. The study template was then registered to the ICBM 152 2009b standard image following an identical 3-step registration pipeline with 4 resolution levels. Details for each registration step are described in (27).

All the participants' combined MT-on images were registered in one step to ICBM 152 space with four linear transformation matrices and two non-linear deformations (Figure 1). Similarly, the QSM, $\mathrm{R}_{2}{ }^{*}$ and SWI maps were registered in one step to ICBM 152 template via three linear and two non-linear transformations.

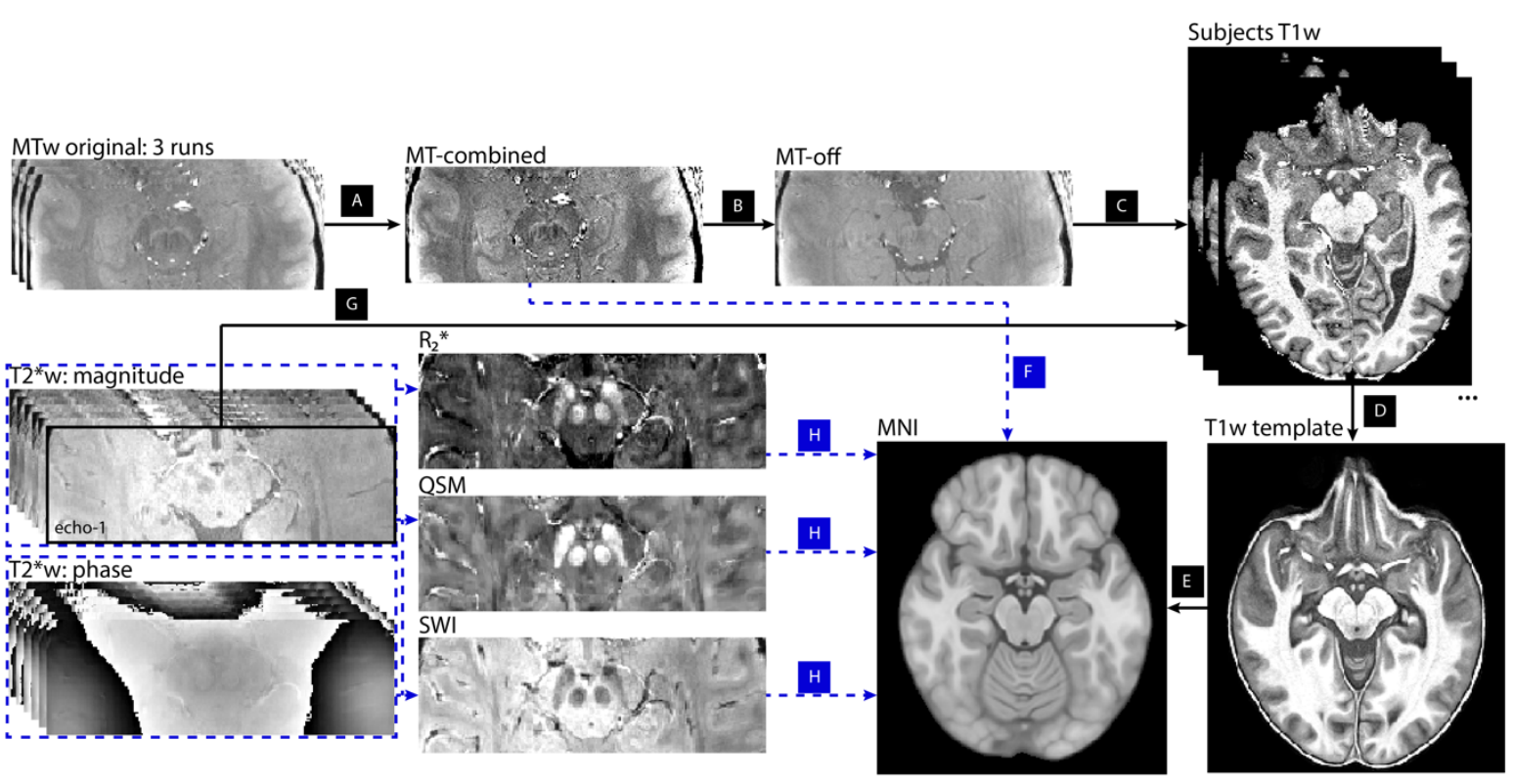

184

Figure 1: Registration pipeline for the MT-w and $\mathrm{T}_{2}{ }^{*}-\mathrm{w}$ data from subject space to the MNI ICBM152 standard brain. For the MT-w data, $(A)$ the individual scans were first combined and registered to the MT-off scan. (B) The latter was used to find the registration between MT space and $T_{1}-w$ space (C). The skull-stripped $\mathrm{T}_{1}-\mathrm{w}$ scans from all subjects were used to create a study-wise template (D) which was then mapped to MNI space via a three-step non-linear registration (E). One single registration was applied on the MT-combined image which included the 4 linear and 2 non-linear transforms to bring the data to the standard space (F). The first echo of the $\mathrm{T}_{2}{ }^{*}-\mathrm{w}$ scans was used to register the $T_{2}{ }^{*}-w$ data into each subjects' $T_{1}-w$ scan (G). The subsequent registration steps to standard space were identical to the MT-w data. The generated QSM, $R_{2}{ }^{*}$ and SWI maps were brought to $\mathrm{MNI}$ space by performing a single registration including one linear and two non-linear transforms $(\mathrm{H})$.

\subsection{Generation of substantia nigra regions-of-interest}

We applied a semi-automated threshold-based method to segment the substantia nigra independently in the MT-on and QSM images, as it has been validated for the substantia nigra 
medRxiv preprint doi: https://doi.org/10.1101/2021.04.13.21255416; this version posted April 20, 2021. The copyright holder for this preprint (which was not certified by peer review) is the author/funder, who has granted medRxiv a license to display the preprint in perpetuity. It is made available under a CC-BY 4.0 International license .

Iron and neuromelanin in PD using 7T MRI - P a g e $\mid 9$

201

202

203

204

205

206

207

208

209

210

211

212

213

214

215

216

217

218

219

220

221

222

223

224

225

226

227

228

229

230

231

232

and smaller brain regions such as the locus coeruleus $(27,46,47)$. The N1-sign was segmented in SWI images with a similar approach.

Since MT-on, and QSM and SWI images show different contrast characteristics in the substantia nigra (48), two different search areas were defined. The search area for the substantia nigra was manually defined bilaterally in ITK-SNAP software v3.6.0 (49) within the midbrain portion of the brainstem ROI defined from MNI template brainstem substructure segmentation in FreeSurfer 6.0 (50) (Supplementary Information Figure 1). The slices that showed hyperintensities in the substantia nigra region were selected.

Cylindrical reference regions were defined in the left and right hemispheres (diameter 3.5 $\mathrm{mm}, 4 \mathrm{~mm}$ height) in the lateral crus cerebri adjacent to the substantia nigra, starting from the most caudal slice with visible hyperintensity in the anatomic region of the substantia nigra in the MT-on and QSM images ( $z=105$ to $z=112$ of the standard ICBM 152 MNI space Supplementary material Figure 1D).

Then, for each subject and image contrast separately, the substantia nigra voxels were thresholded at a level defined by the hemispheric specific reference region: $T=A V_{R E F}+$ $\alpha \times S D_{R E F}$, where $\alpha$ was set to 5 for the QSM and 4 for the MT-on images. For the SWI images, because the contrast within the ref region is similar N1-sign of the substantia nigra, $\alpha$ was set to -1.5 . A resulting binary map for each subject and contrast was built based on the signal that survived the threshold $T$. Each participant's map was added to create a probability density map of the MT-on, QSM and SWI based substantia nigra segmentation, and were thresholded (at 5\% for MT-on, 35\% for QSM, and 25\% for SWI) to obtain the final bilateral ROIs ('MTROI', 'QSMROI' and 'SWIROI', respectively - Figure 2). The SWIROI required further manual adjustments to include only voxels within the MTROI or the QSMROI and not the crus cerebri (Supplementary Figure 3).

Three new bilateral sub-ROIs were defined (Figure 2): the 'Overlap' ROI included voxels that were part both of MTROI and QSMROI; the 'MTOnly' ROI included voxels of the MTROI which were not part of the Overlap ROI; the 'QSMOnly' ROI included voxels of the QSMROI which were not part of the Overlap ROI. 
medRxiv preprint doi: https://doi.org/10.1101/2021.04.13.21255416; this version posted April 20, 2021. The copyright holder for this preprint (which was not certified by peer review) is the author/funder, who has granted medRxiv a license to display the preprint in perpetuity. It is made available under a CC-BY 4.0 International license .

233

234

235

236

237

238

239

240

241

242

243

244

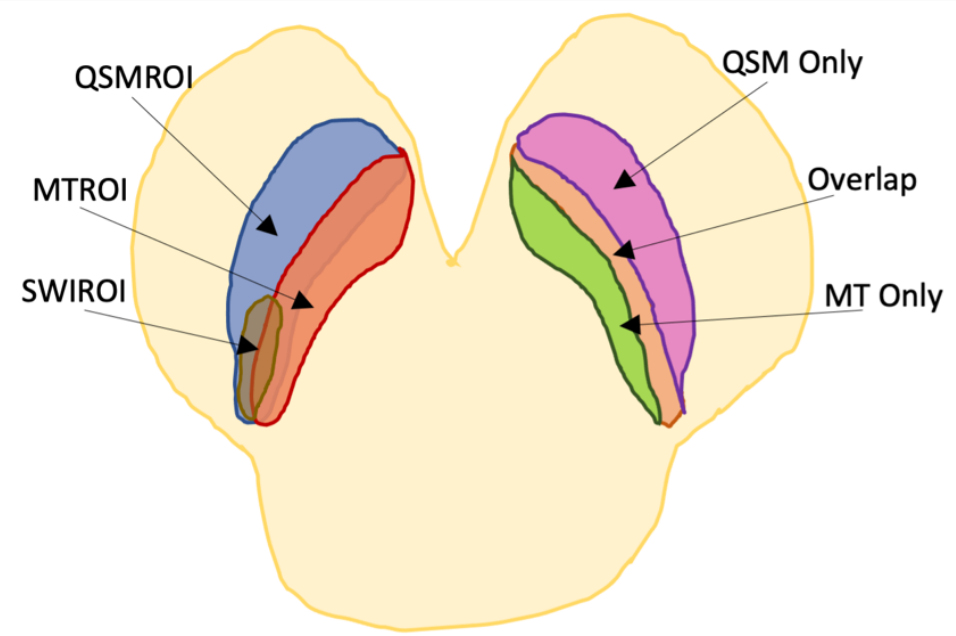

Figure 2: ROI definition in the substantia nigra used in this study identified from an independent cohort. Two ROls were defined based on the substantia nigra QSM hyperintensity ('QSMROI' - blue) and MT-w hyperintensity ('MTROI' - red). The 'SWIROI' (brown) was defined as the hyperintensity in the SWI images within the MTROI and QSMROI. Then, three new ROIs were defined: the 'Overlap' ROI included voxels that were common to the QSMROI and MTROI (orange); the 'QSMOnly' ROI contained voxels that were part of the QSMROI and not of the MTROI (purple); the 'MTOnly' ROI included voxels that were exclusive to the MTROI and not to the QSMROI (green).

\subsection{Signal extraction from the substantia nigra}

In the HC and PD groups, the neuromelanin (combined MT-on) and iron (QSM and $\mathrm{R}_{2}{ }^{*}$ ) maps were mapped to ICBM152 space via a similar pipeline to the $\mathrm{HCi}$ described in section 2.4, with an unbiased $T_{1}$-template created from the individual $T_{1}-w$ MP2RAGE scans from the participants both in the $\mathrm{HC}$ and PD groups.

In standard space, the MT-CNR was computed on the combined MT-on images within an ROI by extracting the difference between the mean signal of the hemisphere specific ROI $\left(\bar{s}_{R O I}\right)$ and the mean intensity in the reference region of the corresponding hemisphere $\left(\bar{S}_{R E F}\right)$, divided by the standard deviation of the reference signal $\left(\sigma_{R E F}\right): C N R=\frac{\bar{s}_{R O I}-\bar{s}_{R E F}}{\sigma_{R E F}}$. In addition, the average QSM- $\Delta \chi, \mathrm{R}_{2}{ }^{*}$ and $\Delta R_{2}^{*} / \Delta \chi$ ratio were extracted from all the ROIs.

\subsection{Statistics}

Statistical tests were performed in R (v1.3.1093). For each region-of-interest (described in section 2.5), distributions of each imaging metric (MT-CNR, QSM- $\Delta \chi, \mathrm{R}_{2}{ }^{*}, \Delta R_{2}^{*} / \Delta \chi$ ratio) were evaluated by fitting data with normal, log-normal, gamma and logistic model distributions. The goodness-of-fit for the parametric distributions were calculated and the distribution which showed the lowest Akaike Information Criterion was then used on a general linear 
medRxiv preprint doi: https://doi.org/10.1101/2021.04.13.21255416; this version posted April 20, 2021. The copyright holder for this preprint (which was not certified by peer review) is the author/funder, who has granted medRxiv a license to display the preprint in perpetuity. It is made available under a CC-BY 4.0 International license .

Iron and neuromelanin in PD using 7T MRI - P a g e | 11

260 mixed effects model (gImer function in $\mathrm{R}$ ). The $\Delta R_{2}^{*} / \Delta \chi$ ratio was fitted with a gamma

261 distribution whereas for all other metrics the Gaussian distribution resulted in the best fit.

262 To compare patients and control imaging metrics, the glmer model included group as a fixed 263 effect of interest, hemisphere as a fixed effect of no interest, with a random effect of 264 participant on the intercept. For statistical inference on the fixed effects, $p$-values were obtained by computing an analysis of deviance table on the fitted model (51). Receiver operating characteristic (ROC) analysis was performed and the area under the curve (AUC) was calculated to evaluate the overall diagnostic performance of each imaging metric in differentiating patient and control groups.

To test for associations with clinical features, linear models were fitted on the imaging data (averaged across both hemispheres) of the patients, separately for each clinical variable (disease duration, MoCA, UPDRS-III, AS-self-Total, BIS-Total, HADS-anxiety, HADSdepression), with age added as a nuisance covariate. To assess laterality effects on the patients, a clinical motor symptom laterality index (MAI) was calculated from the UPDRS-III scores and evaluated against imaging (MT-CNR, $\Delta \chi, \mathrm{R}_{2}{ }^{*}, \Delta R_{2}^{*} / \Delta \chi$ ratio) asymmetry indexes (details provided in supplementary information). Linear models were fitted on each of the imaging asymmetry indexes with MAl as a fixed effect and age as a covariate of no interest. False discovery rate (FDR) corrected $p$-values were extracted from the fits. The corrected $p$ value threshold for significance was 0.05 .

\section{Results}

281

Demographic and clinical characteristics are shown in Table 1. The groups were matched for age, sex, education, and there were no significant difference across the cognitive screening measures or behavioural questionnaires. Parkinson's disease duration was $5 \pm 3$ years.

\subsection{Neuromelanin and iron maps of healthy controls and Parkinson's disease.}

288 Figure 3 shows axial and coronal views of the subject average MT, QSM, $\mathrm{R}_{2}{ }^{*}$ and SWI maps in 289 the substantia nigra region. The right Overlap ROI is outlined in green for all images. 53\% of 290 the MTROI voxels and 19\% of the QSMROI voxels are included in the Overlap ROI. In controls, 291 the location of the Overlap ROI is shown with respect to the N1-sign as observed in the SWI 292 image (red outline - Figure 3D; approx. 25\% and 31\% shared voxels, respectively; Dice=0.3). 
medRxiv preprint doi: https://doi.org/10.1101/2021.04.13.21255416; this version posted April 20, 2021. The copyright holder for this preprint (which was not certified by peer review) is the author/funder, who has granted medRxiv a license to display the preprint in perpetuity.

It is made available under a CC-BY 4.0 International license .

Iron and neuromelanin in PD using 7T MRI - P a g e | 12

293

294

295

296

297

298

299

300

301

302

303

304

305

306

307

308

309

310

311

312

313

MT images show an overall reduction of signal in the substantia nigra in participants with Parkinson's disease compared to healthy controls. For iron-related measures, in participants with Parkinson's disease, the N1 sign is not evident in the SWI images (Figure 3D), which is associated with a local increase in iron concentration as observed by the increased signal in QSM and $\mathrm{R}_{2}{ }^{*}$ in the Overlap ROI (Figure 3B,C).

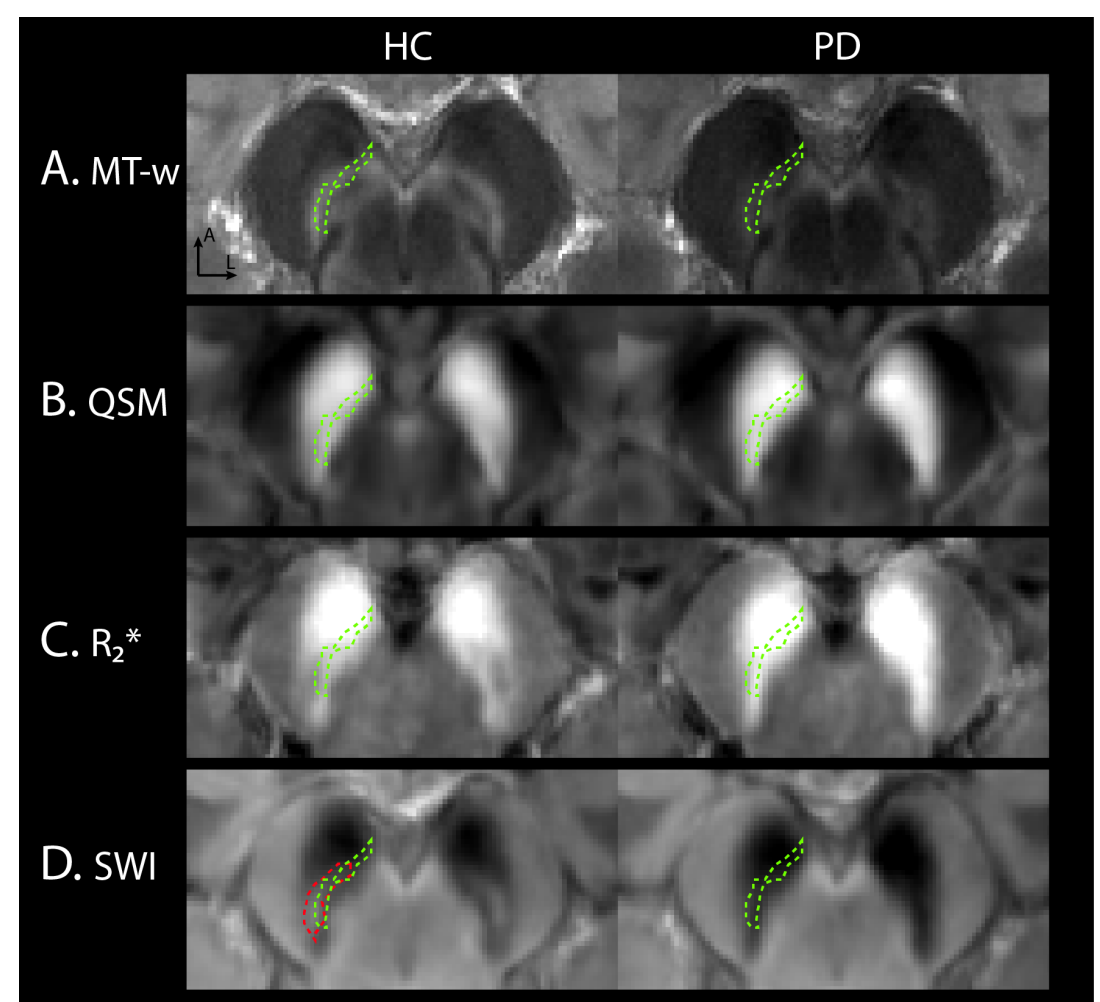

Figure 3: Axial slices of the group average maps showing the substantia nigra region for $\mathrm{HC}$ and PD groups for (A) MT-w, (B) QSM, (C) $\mathbf{R}_{2}{ }^{*}$, (D) SWI. Green outline shows the location of the same right Overlap ROI in all the images. In (D) the right nigrosome-1 (N1) sign is delineated in red.

\subsection{Group statistics}

Compared to controls, participants with Parkinson's disease had reduced neuromelanin signal in all nigral regions-of-interest as measured by MT-CNR (Figure 4A; and Supplementary Information Table 1). This reduction was largest in MT-based (MTROI and MTOnly) and Overlap regions (e.g. $M T-C N R_{H C}=4.6 \pm 2.1$ and $M T-C N R_{P D}=2.4 \pm 1.8$ in the Overlap region) compared to QSM regions. Similarly, QSM- $\Delta \chi$ increased 1.4-fold in MT-driven ROIs and in the Overlap ROI (e.g. $\Delta \chi_{\mathrm{HC}}=0.12 \pm 0.03 \mathrm{ppm}$ and $\Delta \chi_{\mathrm{PD}}=0.15 \pm 0.03 \mathrm{ppm}$ in the Overlap ROI, $\mathrm{p}<$ 0.0001 ) but did not reach statistical significance in the QSMROI, QSMOnly or SWIROI regions (Figure 4B). $\mathrm{R}_{2}$ * showed similar statistics to QSM (Supplementary Information Table 2). The 
medRxiv preprint doi: https://doi.org/10.1101/2021.04.13.21255416; this version posted April 20, 2021. The copyright holder for this preprint (which was not certified by peer review) is the author/funder, who has granted medRxiv a license to display the preprint in perpetuity.

It is made available under a CC-BY 4.0 International license.

Iron and neuromelanin in PD using 7T MRI - P a g e | 13

314 boxplots for the $\Delta R_{2}^{*} / \Delta \chi$ ratio show a local significant increase $(\mathrm{p}=0.0048)$ within the Overlap

315 ROI (Figure 5): compared to controls, the $\Delta R_{2}^{*} / \Delta \chi$ ratio was, on average, $0.031 \mathrm{~ms} / \mathrm{ppm}$ higher

316 in the patient group. Similar significant hemispheric differences were found in patient and

317 control data in all imaging metrics (e.g. SWIROI of Figure 5, p<0.0001).

318

319

320

321

322

323

324

325

326

B
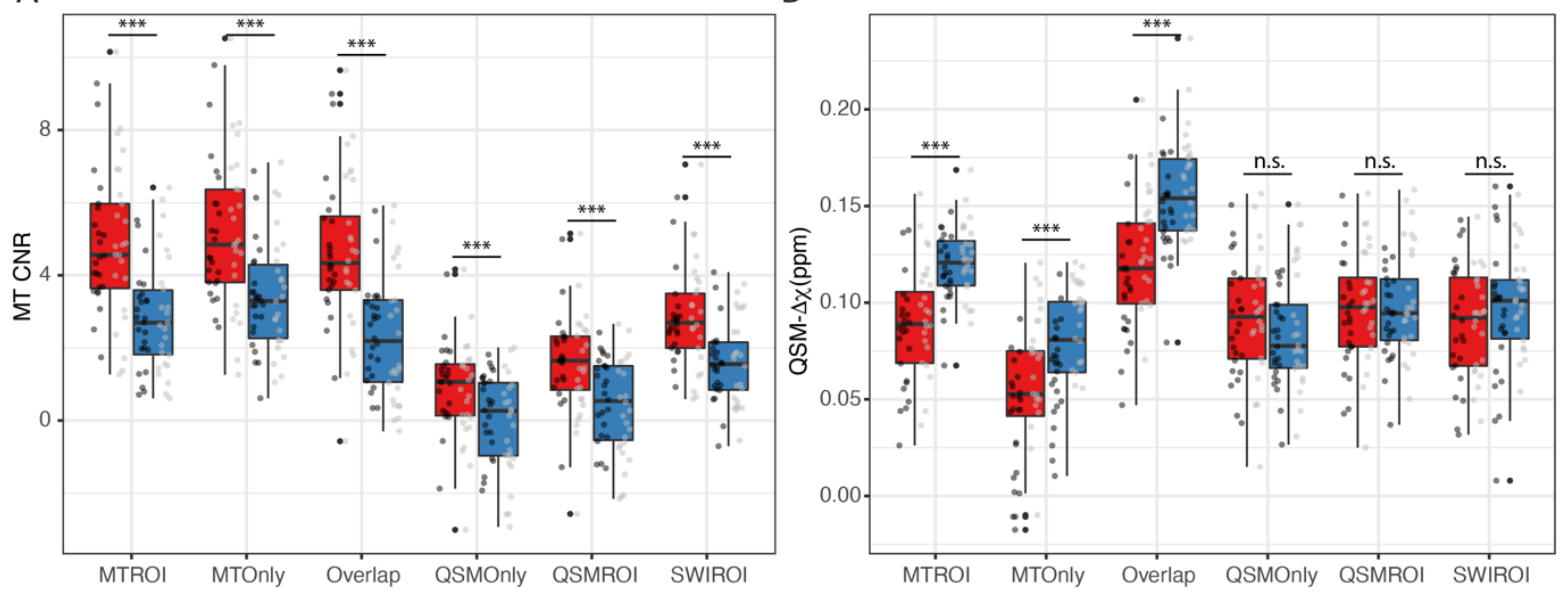

Type 审 HC 送 PD Hemisphere • left •right

Figure 4: Boxplots of the MT-CNR (A) and QSM- $\triangle \chi$ (B) in healthy controls (HC, red) and patients with Parkinson's disease (PD, blue) in the six sub-regions the substantia nigra. Individual subject measures from the left and right hemispheres are overlaid as scatter points. Statistical significance: $*_{* *} p<0.0001 ;{ }^{* *} p<0.01 ;$ n.s. $p>0.05$.

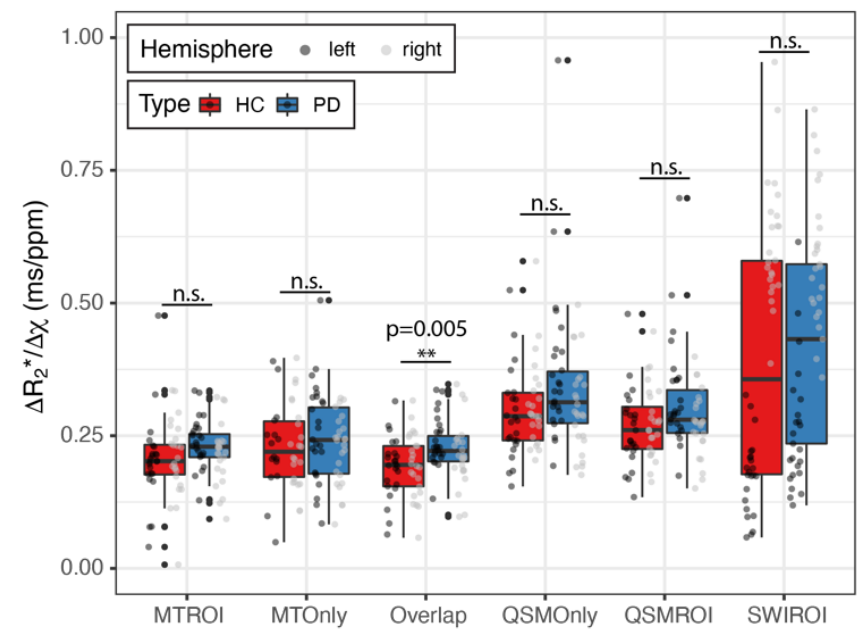

Figure 5: Boxplots of the $\Delta \boldsymbol{R}_{2}^{*} / \Delta \chi$ ratio in healthy controls (HC, red) and patients with Parkinson's disease (PD, blue) in the six sub-regions the substantia nigra. Individual subject measures from the left and right hemispheres are overlaid as scatter points. Statistical significance: $* * * p<0.0001 ; * *$ $p<0.01 ;$ n.s. $p>0.05$. 
medRxiv preprint doi: https://doi.org/10.1101/2021.04.13.21255416; this version posted April 20, 2021. The copyright holder for this preprint (which was not certified by peer review) is the author/funder, who has granted medRxiv a license to display the preprint in perpetuity.

It is made available under a CC-BY 4.0 International license .

Iron and neuromelanin in PD using 7T MRI - P a g e | 14

333

334

335

336

337

338

339

340

341

342

343

\subsection{ROC analysis}

Receiver operating characteristic curves for the MT-CNR, QSM- $\Delta \chi$ and $\Delta R_{2}^{*} / \Delta \chi$ ratio are illustrated in Figure 6. Compared to the other regions-of-interest, the AUC values for the Overlap ROI were the highest when using the MT-CNR data (AUC=0.81; $p<0.0001)$ and the QSM- $\Delta \chi$ data ( $A \cup C=0.83 ; p<0.0001$ ) in differentiating patients with Parkinson's disease from healthy subjects. This indicates that, in the nigra the MT and QSM data share complementary information for differentiating patients from controls. For the $\Delta R_{2}^{*} / \Delta \chi$ ratio the Overlap ROI also showed the largest $A \cup C$ values $(A \cup C=0.67 ; p=0.002)$. The SWIROI defining the N1-sign showed lower AUC values compared to the Overlap ROI in the three imaging metrics (Figure 6).

A

344

345

346

347

348

349

350

351

352

353

354

355

356

357

358

359
B

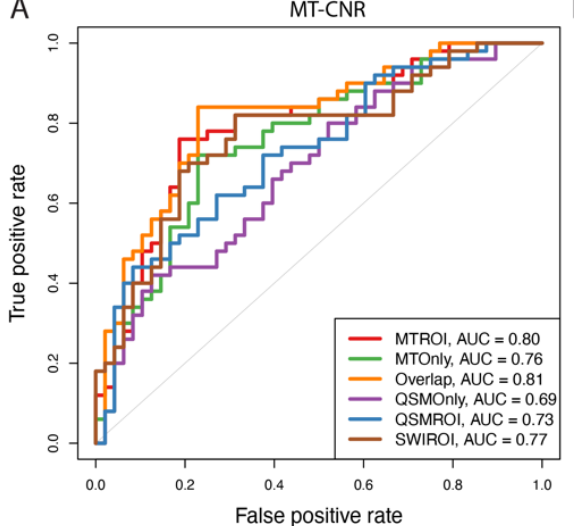

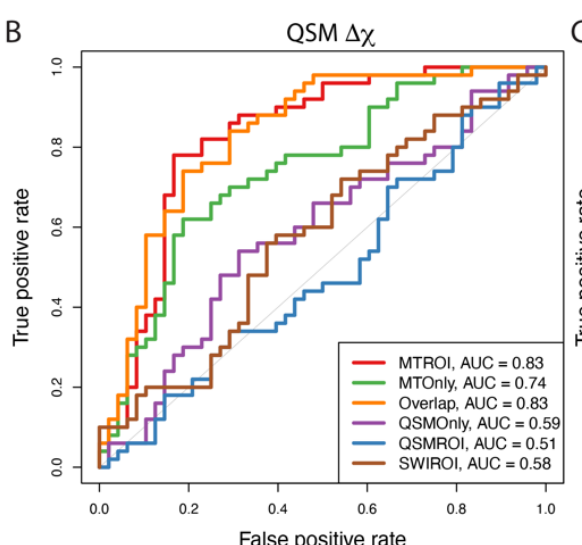

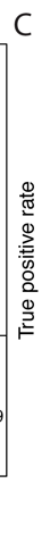

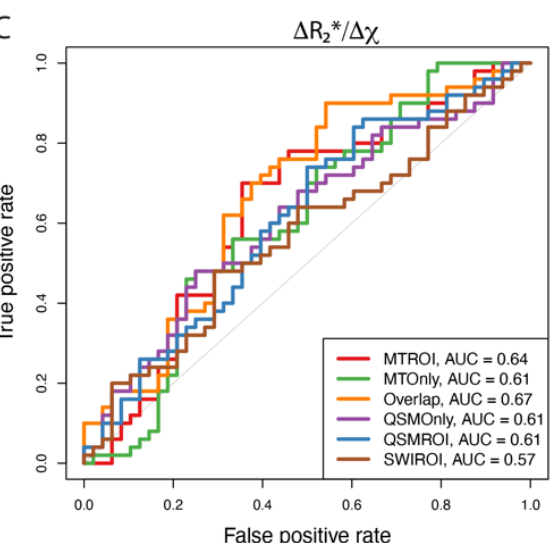

Figure 6: ROC plots for (A) MT-CNR, (B) QSM- $\Delta \chi$ and (C) $\Delta \boldsymbol{R}_{2}^{*} / \Delta \chi$ ratio discriminating patients with Parkinson's disease and healthy controls based on data extracted from the six sub-regions of the substantia nigra. Data from both hemispheres included in the analysis.

\subsection{Associations between imaging and clinical measures}

Disease duration showed a significant positive association with the $\Delta R_{2}^{*} / \Delta \chi$ ratio in all ROls including the overlap ROI $\left(\beta=0.0072 ; p_{f d r}=0.048\right)$ (Figure $\left.7 A\right)$, but not the MTOnly ROI (Supplementary Information Figure 4). Neither QSM nor $\mathrm{R}_{2}{ }^{*}$ alone showed statistically significant associations with disease duration.

Increased $\Delta R_{2}^{*} / \Delta \chi$ ratio was associated with lower MoCA scores in patients within the neuromelanin-rich substantia nigra (Supplementary Information Figure 5), reaching significance in the Overlap ROI (Figure 7B): $\beta=-0.011 ; p_{\mathrm{fdr}}=0.048$. Imaging measures showed no statistically significant associations with motor severity (UPDRS-III) after correction for multiple comparisons $\left(p_{\mathrm{fdr}}>0.3\right)$, apathy scale $\left(p_{\mathrm{fdr}}>0.3\right)$, Barrat impulsiveness scales ( $p_{\mathrm{fdr}}$ 
medRxiv preprint doi: https://doi.org/10.1101/2021.04.13.21255416; this version posted April 20, 2021. The copyright holder for this preprint (which was not certified by peer review) is the author/funder, who has granted medRxiv a license to display the preprint in perpetuity.

It is made available under a CC-BY 4.0 International license .

$360>0.2)$, and anxiety and depression scales $\left(\mathrm{p}_{\mathrm{fdr}}>0.3\right)$. No significant associations were found 361 when evaluating the imaging laterality indexes against clinical motor symptom laterality 362 indexes in all subregions of the substantia nigra.

A

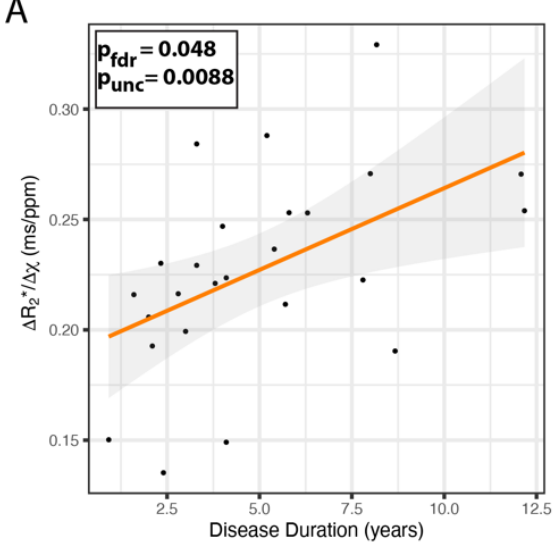

B

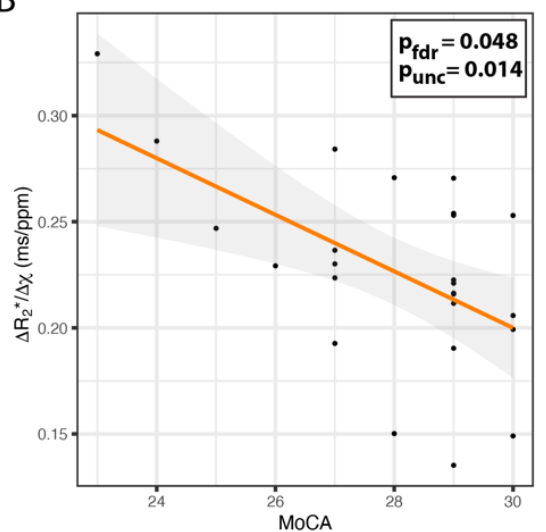

Figure 7: Relationship between the $\Delta \boldsymbol{R}_{2}^{*} / \Delta \chi$ ratio and clinical characteristics of disease duration in years (A) and MoCA score (B) in the Parkinson's disease group in the Overlap ROI. Uncorrected and FDR-corrected $p$-values are reported in each plot for the linear fits.

\section{Discussion}

370 This study reveals the impact of Parkinson's disease on neuromelanin (by MT contrast) and

371 iron (by susceptibility quantities - QSM and $\mathrm{R}_{2}{ }^{*}$ ), using ultra-high field high-resolution 372 magnetic resonance imaging of the substantia nigra. We defined two main regions-of373 interest. In healthy individuals, MT-CNR was highest in the inferoventral region of the 374 substantia nigra, whereas increased susceptibility was greatest in the superolateral region.

375 As reported in previous imaging studies $(48,52,53)$, these two regions represent to some degree the difference between the classically defined pars compacta and pars reticulata.

377 The pars compacta has closely packed pigmented neurons, while the pars reticulata shows

378 scattered non-pigmented neurons in a reticular neuropil (54). Our 7T high-resolution imaging showed the additional definition of subregions associated to the substantia nigra based on the MT and QSM measures. We found that a sub-region showing increase of both these contrasts, the Overlap ROI, in healthy controls consistent with the anatomical location of the ventral portion of the SNpc ( $\mathrm{VSNpc}$ ), was the most sensitive to differentiating Parkinson's disease as supported by the highest AUC on ROC analysis (Figure 6). This demonstrates that proxy MRI measures of neuromelanin loss and increased iron accumulation are complementary indices that help discriminating patients with Parkinson's disease from controls. A similar three layer organisation has been proposed by Cosottini et al. (55). 
medRxiv preprint doi: https://doi.org/10.1101/2021.04.13.21255416; this version posted April 20, 2021. The copyright holder for this preprint (which was not certified by peer review) is the author/funder, who has granted medRxiv a license to display the preprint in perpetuity. It is made available under a CC-BY 4.0 International license.

Iron and neuromelanin in PD using 7T MRI - P a g e | 16

387 Brammerloh et al. (56) demonstrated the dominant $R_{2}{ }^{*}$ contribution of iron bound to

388 neuromelanin of pigmented neurons, reinforcing the importance of imaging the substantia

389 nigra in subregions with multi-contrast techniques. From our data, segmentation of $\mathrm{R}_{2}{ }^{*}$-based

390 substantia nigra showed a similar ROI definition to the QSM (Supplementary Information

391 Figure 2, Dice=0.7). We found that the Overlap ROI shares a similar location to the N1-sign

392 obtained with SWI (Dice=0.3), but not completely (red and green outlines in Figure 3).

393 Segmentation was performed on an independent healthy control group using the same

394 imaging strategy as in the group study in MNI space with the purpose of reducing ROI

395 selection bias.

396 Magnetization transfer contrast was reduced in Parkinson's disease, suggestive of lower

397 neuromelanin content as described in imaging and post-mortem studies $(13,17,53,57-59)$. In

398 addition, increased susceptibility- $\chi$ and $R_{2}{ }^{*}$ was found in patients in sub-regions driven by the

399 MT-ROI, but not on regions exclusively showing high-susceptibility contrast in healthy

400 controls. In our analyses, reduction of MT-CNR and increased QSM and $\mathrm{R}_{2}{ }^{*}$ was most

401 significant in the Overlap ROI. These results are supported by the ROC analysis (Figure 6). Our

402 results also show that the N1-sign region alone does not show improved detectability of the

403 disease in any of the imaging metrics studied. This indicated the importance of combining

404 QSM and MT-w imaging for Parkinson's disease diagnosis. Similar studies have reported the 405 increase of susceptibility MR signal in the pars compacta region in patients with Parkinson's 406 disease (60-62) and, more recently, Bergsland et al. (63) narrowed it to the ventral portion.

407 In (55) the hyperintensity loss in SWI images was better detected in the intermediate layer of

408 the substantia nigra rich in dopaminergic neurons, the ventral portion of the SNpc, which in

409 accordance with our definition of the Overlap ROI.

410 Distinguishing types of iron in the brain with MRI in vivo is challenging. Here we referred to

$411 \mathrm{R}_{2}{ }^{*}$-to- $\chi$ ratio as an indirect estimate of the ferric $\left(\mathrm{Fe}^{3+}\right)$ to ferrous $\left(\mathrm{Fe}^{2+}\right)$ load in the brain. Our

412 results show that, in patients, there is a significant increase of this ratio within the ventral

413 portion of the SNpc. We differentiated iron markers in MRI in Parkinson's patients by

414 combining both magnitude and phase data from a single MRI acquisition. The $R_{2}{ }^{*}$-to- $\chi$ ratio

415 as a proxy for ferric to ferrous loading has been previously validated in phantom work using

$416 \mathrm{MRI}$ in (25). However, in future, post-mortem MRI imaging together with histological iron

417 staining is still required to validate this measure in healthy and diseased tissue.

418 Reports of the correlation of imaging and clinical outcomes in Parkinson's disease are diverse. 
medRxiv preprint doi: https://doi.org/10.1101/2021.04.13.21255416; this version posted April 20, 2021. The copyright holder for this preprint (which was not certified by peer review) is the author/funder, who has granted medRxiv a license to display the preprint in perpetuity. It is made available under a CC-BY 4.0 International license .

Iron and neuromelanin in PD using 7T MRI - P a g e | 17

419 Some have shown disease duration has a positive correlation with susceptibility measures

420 (QSM or $\left.\mathrm{R}_{2}{ }^{*}\right)$ in the substantia nigra $(60,63-65)$ while others showed a weak to no correlation

$421(22,48)$. When corrected for age, we found that only the $R_{2}{ }^{*}$-to- $\chi$ ratio positively associated

422 with disease duration, and most significantly in neuromelanin rich areas, including the

423 Overlap ROI. Our results are in line with previous post mortem studies (Figure 1 from Youdim

424 et al. (66)). Parkinson's disease patients appear to show an imbalance of the $\mathrm{Fe}^{3+}: \mathrm{Fe}^{2+}$ ratio

425 which is required for lipid peroxidation, resulting not only in an increased $\mathrm{Fe}^{3+}$-melanin

426 complex in neuromelanin-pigmented neurons (67) but also of free iron because the

427 neuromelanin buffering capacities towards iron became exhausted. This leads to toxicity and

428 to oxygen radical-induced death of neuromelanin-pigmented dopaminergic cell populations.

429 Histopathological studies such as $(68,69)$ show a negative correlation between the number of

430 pigmented neurons in the substantia nigra and clinical features such as disease duration or

431 UPDRS-scores. In Biondetti et al. (70), neuromelanin-sensitive imaging correlated with motor,

432 cognitive and mood/behavioural clinical scores in distinct regions of the substantia nigra. In

433 our study, no neuromelanin markers correlated with clinical outcomes. This may be explained

434 by the lack of granularity of our broad clinical measures compared to (70), and to the early

435 stage of disease in our cohort ( $5 \pm 3$ years from onset, Hoehn and Yahr 1.5-3) which may show

436 a highly variable neuronal density loss within the substantia nigra: Kordower et al. (68)

437 reported a wide range (33-80\%) in the reduction of neuromelanin-containing neurons within

$438 \quad 5-7$ years post-PD diagnosis.

$439 \mathrm{~T}_{2}{ }^{*}$-MRI (mathematical inverse of $\mathrm{R}_{2}{ }^{*}$ ) has been found to positively correlate with cognitive

440 dysfunction in Parkinson's disease in Tambasco et al. (71), but other studies have not found

441 any strong correlations (72). From our data, patients that showed higher ferric loading (higher

$442 \mathrm{R}_{2}{ }^{*}$-to- $\chi$ ratio) within the Overlap region definition of the substantia nigra had lower MoCA

443 scores (i.e. worse cognition). Our data is consistent with the suggestion that the loss of

444 neuromelanin-rich dopaminergic neurons and increased neurodegeneration lead to cognitive

445 impairment. Neither $\mathrm{R}_{2}$ * or QSM alone correlated with the MoCA score. This may be due to

446 the lack of sensitivity of cognitive screening tests in non-demented patients and those

447 without mild cognitive impairment, and also the specificity of the molecular correlates of our

448 sequences in contrast to volumetric, spectroscopic or diffusion properties of other MR

449 sequences. To associate our high-resolution MRI metrics with clinical outcomes, advanced

450 stage patients may be required (65). 
medRxiv preprint doi: https://doi.org/10.1101/2021.04.13.21255416; this version posted April 20, 2021. The copyright holder for this preprint (which was not certified by peer review) is the author/funder, who has granted medRxiv a license to display the preprint in perpetuity. It is made available under a CC-BY 4.0 International license .

Iron and neuromelanin in PD using 7T MRI - P a g e | 18

451 We demonstrate the usefulness of a neuromelanin-iron multimodal imaging approach.

452 However, the addition of diffusion scalars similar to (73) at high-resolution would provide

453 additional quantitative values of the microstructural integrity (e.g. myelin) and intra- to extra454 cellular water diffusion variations within the nigra compartments that could aid 455 characterization of the neurodegeneration in Parkinsonian disorders.

456 Hemispheric effects were found on both control and patient data, particularly evident on smaller ROIs (e.g. results for the SWIROI in Figure 5). Yet, we found no associations between imaging and clinical motor symptom laterality. The hemispheric asymmetry on the imaging results might be related to the known asymmetry in the $\mathrm{B}_{1}{ }^{+}$transmit profile which occurs when using transmit-receive coils such as the coil used in our study in circular-polarised mode $(74,75)$. In our analysis, we controlled for hemisphere effects by either adding a fixed variable of no interest on the general linear modelling statistics or by averaging the data across both hemispheres. Magnetization transfer imaging shows specificity to the dopaminergic neurons of the SNpc but its biological relationship with neuromelanin is still elusive (76-78) as a contrast-to-noise measurement is only semi-quantitative. In order to better quantify nonexchangeable protons attached to macromolecules like neuromelanin, kinetic model parameters describing magnetization dynamics via a two-pool model could be used $(79,80)$. Susceptibility and $R_{2} *$ mapping have the advantage of quantifying iron-related microscopic field changes, and so provide a more biologically meaningful clinical indicator of the pathogenesis. Therefore, the combination of these two imaging techniques provide a more holistic understanding of the neurodegeneration in the dopaminergic pathway within the substantia nigra and a more sensitive approach in differentiating patients with Parkinson's disease from healthy controls.

In conclusion, the complementary information from iron and neuromelanin high-resolution ultra-high field 7T imaging allowed the detection of ferric $\left(\mathrm{Fe}^{3+}\right)$ overload and neuromelanin loss on Parkinson's patients in an area of the substantia nigra with both high neuromelanin and susceptibility MRI signal in normal controls. In addition, patients at later stages of the disease show higher ferric loading and lower cognitive function which is in accordance with histopathological findings. Our results suggest that ultra-high field 7T MT-weighted and T2*_ weighted imaging are sensitive to the detection of molecular change in Parkinson's disease, and may therefore support future experimental medicines strategies. 
medRxiv preprint doi: https://doi.org/10.1101/2021.04.13.21255416; this version posted April 20, 2021. The copyright holder for this preprint (which was not certified by peer review) is the author/funder, who has granted medRxiv a license to display the preprint in perpetuity. It is made available under a CC-BY 4.0 International license .

Iron and neuromelanin in PD using 7T MRI - P a g e | 19

483

484

485

486

487

488

489

490

491

492

493

494

495

496

497

498

499

500

501

502

503

504

505

506

507

508

509

510

511

512 513 Manuscript (Review and Critique).

\section{Acknowledgements:}

We acknowledge the NIHR Cambridge Clinical Research Facility and the NIHR Cambridge Biomedical Research Centre (BRC-1215-20014), the Medical Research Council (MR/M008983/1, SUAG/051 G101400, MR/P01271X/1), the Wellcome Trust (103838), the Wellcome Trust \& Royal Society (098436/Z/12/B), and the Cambridge Centre for Parkinsonplus (RG95450), Parkinson's UK (K-1702), a Neil Hamilton Fairley Fellowship from the Australian National Health and Medical Research Council (GNT1091310), the Chinese Scholarship Council, a Cambridge Trust Vice-Chancellor's Award and Fitzwilliam College. The views expressed are those of the authors and not necessarily those of the NHS, the NIHR or the Department of Health and Social Care. This is an open access article distributed under the Creative Commons Attribution License 4.0 (CCBY), which permits unrestricted use, distribution, and reproduction in any medium, provided the original work is properly cited.

\section{Authors Roles:}

Catarina Rua: Research Project (Conception, Organization, Execution), Statistical Analysis (Design, Execution, Review), Manuscript (Writing first draft, Review and Critique).

Claire O'Callaghan: Research Project (Conception, Organization, Execution), Statistical Analysis (Design, Review), Manuscript (Review and Critique).

Rong Ye: Research Project (Organization, Execution), Statistical Analysis (Design, Review), Manuscript (Review and Critique).

Frank H Hezemans: Research Project (Organization, Execution), Statistical Analysis (Review), Manuscript (Review and Critique).

Luca Passamonti: Research Project (Conception), Manuscript (Review and Critique).

P Simon Jones: Statistical Analysis (Design, Review), Manuscript (Review and Critique).

Guy B Williams: Research Project (Conception, Organization), Manuscript (Review and Critique).

Christopher T Rodgers: Research Project (Conception), Manuscript (Review and Critique).

James B Rowe: Research Project (Conception, Organization), Statistical Analysis (Review), 
medRxiv preprint doi: https://doi.org/10.1101/2021.04.13.21255416; this version posted April 20, 2021. The copyright holder for this preprint (which was not certified by peer review) is the author/funder, who has granted medRxiv a license to display the preprint in perpetuity. It is made available under a CC-BY 4.0 International license .

Iron and neuromelanin in PD using 7T MRI - P a g e $\mid 20$

514

515

516

517

518

519

520

521

522

523

524

525

526

527

528

529

530

531

532

533

534

535

536

537

538

539

540

541

542

543

544

545

546

547

548

549

550

551

552

553

554

555

556

557

\section{References:}

1. Hirsch EC, Brandel J -P, Galle P, Javoy-Agid F, Agid Y. Iron and Aluminum Increase in the Substantia Nigra of Patients with Parkinson's Disease: An X-Ray Microanalysis. J Neurochem. 1991;56(2):446-51.

2. Kitao S, Matsusue E, Fujii S, Miyoshi F, Kaminou T, Kato S, et al. Correlation between pathology and neuromelanin MR imaging in Parkinson's disease and dementia with Lewy bodies. Neuroradiology. 2013;55(8):947-53.

3. Vaillancourt DE, Mitchell T. Parkinson's disease progression in the substantia nigra: location, location, location. Brain. 2020;143(9):2728-2630.

4. Zecca L, Wilms H, Geick S, Claasen JH, Brandenburg LO, Holzknecht C, et al. Human neuromelanin induces neuroinflammation and neurodegeneration in the rat substantia nigra: Implications for Parkinson's disease. Acta Neuropathol. 2008;116(1):47-55. 5. Götz ME, Double K, Gerlach M, Youdim MBH, Riederer P. The relevance of iron in the
pathogenesis of Parkinson's disease. Ann N Y Acad Sci. 2004;1012(March):193-208.

6. Double KL, Ben-Shachar D, Youdim MBH, Zecca L, Riederer P, Gerlach M. Influence of neuromelanin on oxidative pathways within the human substantia nigra. Neurotoxicol Teratol. 2002;24(5):621-8.

7. Eid R, Arab NTT, Greenwood MT. Iron mediated toxicity and programmed cell death: A review and a re-examination of existing paradigms. Biochim Biophys Acta - Mol Cell Res [Internet]. 2017;1864(2):399-430. Available from: http://dx.doi.org/10.1016/j.bbamcr.2016.12.002

8. Youdim MB. Iron in the brain: implications for Parkinson's and Alzheimer's diseases. Mt Sinai J Med [Internet]. 1988 Jan;55(1):97-101. Available from: http://europepmc.org/abstract/MED/3279308

9. Braak H, Del Tredici K, Rüb U, De Vos RAI, Jansen Steur ENH, Braak E. Staging of brain pathology related to sporadic Parkinson's disease. Neurobiol Aging. 2003;24(2):197-211.

10. Zucca FA, Segura-Aguilar J, Ferrari E, Muñoz P, Paris I, Sulzer D, et al. Interactions of iron, dopamine and neuromelanin pathways in brain aging and Parkinson's disease. Prog Neurobiol. 2017;155:96-119.

11. Zucca FA, Bellei C, Giannelli S, Terreni MR, Gallorini M, Rizzio E, et al. Neuromelanin and iron in human locus coeruleus and substantia nigra during aging: Consequences for neuronal vulnerability. J Neural Transm. 2006;113(6):757-67.

12. Grifiths PD, Dobson BR, Jones GR, Clarke DT. Iron in the basal ganglia in Parkinson's disease. An in vivo study using extended $\mathrm{X}$-ray absorption fine structure and cryo-electron microscopy. Brain. 1999;122(4):667-73.

13. Isaias IU, Trujillo P, Summers P, Marotta G, Mainardi L, Pezzoli G, et al. Neuromelanin imaging and dopaminergic loss in parkinson's disease. Front Aging Neurosci. 2016;8(AUG):1-12.

14. Wakamatsu K, Fujikawa K, Zucca FA, Zecca L, Ito S. The structure of neuromelanin as studied by chemical degradative methods. J Neurochem. 2003;86(4):1015-23.

15. Sasaki M, Shibata E, Tohyama K, Takahashi J, Otsuka K, Tsuchiya K, et al. Neuromelanin magnetic resonance imaging of locus ceruleus and substantia nigra in Parkinson's disease. Neuroreport. 2006;17(11):1215-8.

16. Reimão $S$, Ferreira $S$, Nunes RG, Pita Lobo $P$, Neutel $D$, Abreu D, et al. Magnetic resonance correlation of iron content with neuromelanin in the substantia nigra of early-stage 
medRxiv preprint doi: https://doi.org/10.1101/2021.04.13.21255416; this version posted April 20, 2021. The copyright holder for this preprint (which was not certified by peer review) is the author/funder, who has granted medRxiv a license to display the preprint in perpetuity.

It is made available under a CC-BY 4.0 International license .

Iron and neuromelanin in PD using 7T MRI - P a g e | 21

Parkinson's disease. Eur J Neurol. 2016;23(2):368-74.

17. Prasad S, Stezin A, Lenka A, George L, Saini J, Yadav R, et al. Three-dimensional neuromelanin-sensitive magnetic resonance imaging of the substantia nigra in Parkinson's disease. Eur J Neurol. 2018;25(4):680-6.

18. Keren NI, Taheri S, Vazey EM, Morgan PS, Granholm ACE, Aston-Jones GS, et al. Histologic validation of locus coeruleus MRI contrast in post-mortem tissue. Neuroimage [Internet]. 2015;113:235-45. Available from: http://dx.doi.org/10.1016/j.neuroimage.2015.03.020

19. Haacke EM, Cheng NYC, House MJ, Liu Q, Neelavalli J, Ogg RJ, et al. Imaging iron stores in the brain using magnetic resonance imaging. Magn Reson Imaging. 2005;23(1):1-25.

20. Lotfipour AK, Wharton S, Schwarz ST, Gontu V, Schäfer A, Peters AM, et al. High resolution magnetic susceptibility mapping of the substantia nigra in Parkinson's disease. J Magn Reson Imaging. 2012;35(1):48-55.

21. Barbosa JHO, Santos AC, Tumas V, Liu M, Zheng W, Haacke EM, et al. Quantifying brain iron deposition in patients with Parkinson's disease using quantitative susceptibility mapping, R2 and R2*. Magn Reson Imaging [Internet]. 2015;33(5):559-65. Available from: http://dx.doi.org/10.1016/j.mri.2015.02.021

22. Acosta-Cabronero J, Cardenas-Blanco A, Betts MJ, Butryn M, Valdes-Herrera JP, Galazky I, et al. The whole-brain pattern of magnetic susceptibility perturbations in Parkinson's disease. Brain. 2017;140(1):118-31.

23. Rua C, Clarke WT, Driver ID, Mougin O, Morgan AT, Clare S, et al. Multi-centre, multi-vendor reproducibility of 7T QSM and R2* in the human brain: Results from the UK7T study. Neuroimage [Internet]. 2020;223(April):117358. Available from: https://doi.org/10.1016/j.neuroimage.2020.117358

24. Cheng Z, He N, Huang P, Li Y, Tang R, Sethi SK, et al. Imaging the Nigrosome 1 in the substantia nigra using susceptibility weighted imaging and quantitative susceptibility mapping: An application to Parkinson's disease. Neurolmage Clin [Internet]. 2020;25(May 2019):102103. Available from: https://doi.org/10.1016/j.nicl.2019.102103

25. Dietrich O, Levin J, Giese A, Plate A, Bötzel K, Reiser MF, et al. Differentiation of Fe2+ and Fe3+ with iron-sensitive MRI. In: Proceedings 22nd Scientific Meeting, International Society for Magnetic Resonance in Medicine. 2013. p. 2482.

26. Priovoulos N, Jacobs HIL, Ivanov D, Uludağ K, Verhey FRJ, Poser BA. High-resolution in vivo imaging of human locus coeruleus by magnetization transfer MRI at 3T and 7T. Neuroimage [Internet]. 2018;168(July):427-36. Available from: http://dx.doi.org/10.1016/j.neuroimage.2017.07.045

27. Ye R, Rua C, O'Callaghan C, Jones PS, Hezemans FH, Kaalund SS, et al. An in vivo probabilistic atlas of the human locus coeruleus at ultra-high field. Neuroimage [Internet]. 2021;225(September 2020):117487. Available from: https://doi.org/10.1016/j.neuroimage.2020.117487

28. Tokuhiro T, Appleby A, Leghrouz A, Metcalf R, Tokarz R. Proton spin-lattice relaxation of water molecules in ferrous-ferric/agarose gel system. J Chem Phys. 1996;105(9):3761-9.

29. Martinez-Martin P, Falup-Pecurariu C, Rodriguez-Blazquez C, Serrano-Dueñas M, Carod Artal FJ, Rojo Abuin JM, et al. Dementia associated with Parkinson's disease: Applying the Movement Disorder Society Task Force criteria. Park Relat Disord [Internet]. 2011;17(8):6214. Available from: http://dx.doi.org/10.1016/j.parkreldis.2011.05.017

30. Weintaub D, Koester J, Potenza MN, Siderowf AD, Stacy M, Voon V, et al. Impulse Control 
medRxiv preprint doi: https://doi.org/10.1101/2021.04.13.21255416; this version posted April 20, 2021. The copyright holder for this preprint (which was not certified by peer review) is the author/funder, who has granted medRxiv a license to display the preprint in perpetuity. It is made available under a CC-BY 4.0 International license .

Iron and neuromelanin in PD using 7T MRI - P a g e $\mid 22$

603

604

605

606

607

608

609

610

611

612

613

614

615

616

617

618

619

620

621

622

623

624

625

626

627

628

629

630

631

632

633

634

635

636

637

638

639

640

641

642

643

644

645

646

Disorders in Parkinson Disease. Arch Neurol. 2010;67(5):589-95.

31. Tomlinson CL, Stowe R, Patel S, Rick C, Gray R, Clarke CE. Systematic review of levodopa dose equivalency reporting in Parkinson's disease. Mov Disord. 2010;25(15):2649-53.

32. Goetz CG, Nutt JG, Stebbins GT. The unified dyskinesia rating scale: Presentation and clinimetric profile. Mov Disord. 2008;23(16):2398-403.

33. Folstein MF, Folstein SE. Mini-Mental State: a practical method for grading the cognitive state of patients for the clinician. Int J Geriatr Psychiatry. 1975;12:189-98.

34. Nasreddine ZS, Phillips NA, Bédirian V, Charbonneau S, Whitehead V, Collin I, et al. The Montreal Cognitive Assessment, MoCA: A brief screening tool for mild cognitive impairment. J Am Geriatr Soc. 2005;53(4):695-9.

35. Zigmond AS, Snaith RP. The Hospital Anxiety and Depression Scale. Acta Psychiatr Scand. 1983;67:361-70.

36. Patton JH, Stanford MS, Barratt ES. Factor structure of the barratt impulsiveness scale. J Clin Psychol. 1995;51(6):768-74.

37. Starkstein SE, Mayberg HS, Preziosi TJ, Andrezejewski P, Leiguarda R, Robinson RG. Reliability, validity, and clinical correlates of apathy in Parkinson's disease. J Neuropsychiatry Clin Neurosci. 1992;4(2):134-9.

38. Roemer PB, Edelstein WA, Hayes CE, Souza SP, Mueller OM. The NMR phased array. Magn Reson Med. 1990;16(2):192-225.

39. Mougin O, Clarke WT, Driver I, Rua C, Morgan AT, Francis S, et al. Robustness of PSIR segmentation and R1 mapping at 7T: a travelling head study. In: Proceedings 27th Scientific Meeting, International Society for Magnetic Resonance in Medicine. Paris; 2017. p. 237.

40. Acosta-Cabronero J, Milovic C, Mattern H, Tejos C, Speck O, Callaghan MF. A robust multiscale approach to quantitative susceptibility mapping. Neuroimage [Internet]. 2018;183(June):7-24. Available from: https://doi.org/10.1016/j.neuroimage.2018.07.065

41. Pei M, Nguyen TD, Thimmappa ND, Salustri C, Dong F, Cooper MA, et al. Algorithm for fast monoexponential fitting based on Auto-Regression on Linear Operations (ARLO) of data. Magn Reson Med. 2015;73(2):843-50.

42. Li N, Wang W-T, Sati P, Pham DL, Butman JA. Quantitative assessment of susceptibility weighted imaging processing methods. J Magn Reson Imaging [Internet]. 2014;40(6):146373. Available from: https://www.ncbi.nlm.nih.gov/pmc/articles/PMC3624763/pdf/nihms412728.pdf

43. Clarke WT, Mougin O, Driver ID, Rua C, Morgan AT, Asghar M, et al. Multi-site harmonization of 7 tesla MRI neuroimaging protocols. Neuroimage [Internet]. 2020;206(October 2019):116335. Available from: https://doi.org/10.1016/j.neuroimage.2019.116335

44. Fonov V, Evans AC, Botteron K, Almli CR, McKinstry RC, Collins DL. Unbiased average ageappropriate atlases for pediatric studies. Neuroimage [Internet]. 2011;54(1):313-27. Available from: http://dx.doi.org/10.1016/j.neuroimage.2010.07.033

45. Avants BB, Epstein CL, Grossman M, Gee JC. Symmetric diffeomorphic image registration with cross-correlation: Evaluating automated labeling of elderly and neurodegenerative brain. Med Image Anal. 2008;12(1):26-41.

46. Langley J, Huddleston DE, Sedlacik J, Boelmans K, Hu XP. Parkinson's disease-related increase of T2*-weighted hypointensity in substantia nigra pars compacta. Mov Disord.

2017;32(3):441-9. 
medRxiv preprint doi: https://doi.org/10.1101/2021.04.13.21255416; this version posted April 20, 2021. The copyright holder for this preprint (which was not certified by peer review) is the author/funder, who has granted medRxiv a license to display the preprint in perpetuity.

It is made available under a CC-BY 4.0 International license .

Iron and neuromelanin in PD using 7T MRI - P a g e $\mid 23$

647

648

649

650

651

652

653

654

655

656

657

658

659

660

661

662

663

664

665

666

667

668

669

670

671

672

673

674

675

676

677

678

679

680

681

682

683

684

685

686

687

688

689

690

691

47. Chen X, Huddleston DE, Langley J, Ahn S, Barnum CJ, Factor SA, et al. Simultaneous imaging of locus coeruleus and substantia nigra with a quantitative neuromelanin MRI approach. Magn Reson Imaging [Internet]. 2014;32(10):1301-6. Available from: http://dx.doi.org/10.1016/j.mri.2014.07.003

48. He N, Ghassaban $\mathrm{K}$, Huang $\mathrm{P}$, Jokar $\mathrm{M}$, Wang $\mathrm{Y}$, Cheng $\mathrm{Z}$, et al. Imaging Iron and Neuromelanin Simultaneously Using a Single 3D Magnetization Transfer Sequence: Combining Neuromelanin, Iron and the Nigrosome-1 Sign as Complementary Imaging Biomarkers in Early Stage Parkinson's Disease. Neuroimage [Internet]. 2021;21:117810. Available from: https://doi.org/10.1016/j.neuroimage.2021.117810

49. Yushkevich PA, Piven J, Hazlett HC, Smith RG, Ho S, Gee JC, et al. User-guided 3D active contour segmentation of anatomical structures: Significantly improved efficiency and reliability. Neuroimage. 2006;31(3):1116-28.

50. Eugenio J, Leemput K Van, Bhatt $P$, Casillas $C$, Dutt $S$, Schuff N, et al. Neurolmage Bayesian segmentation of brainstem structures in MRI. Neuroimage [Internet]. 2015;113:184-95. Available from: http://dx.doi.org/10.1016/j.neuroimage.2015.02.065

51. Singmann $\mathrm{H}$, Kellen D. An Introduction to Mixed Models for Experimental Psychology. New Methods Cogn Psychol. 2019;4-31.

52. Langley J, Huddleston DE, Chen X, Sedlacik J, Zachariah N, Hu X. A multicontrast approach for comprehensive imaging of substantia nigra. Neuroimage. 2015;112(404):7-13.

53. Damier $P$, Hirsch EC, Agid Y, Graybiel AM. The substantia nigra of the human brain: II. Patterns of loss of dopamine-containing neurons in Parkinson's disease. Brain. 1999;122(8):1437-48.

54. Nieuwenhuys R, Voogd D, van Huijzen C. The Human Central Nervous System. SpringerVerlag. Germany; 2008.

55. Cosottini M, Frosini D, Pesaresi I, Costagli M, Biagi L, Cerabolo R, et al. MR Imaging of the Substantia Nigra at 7 T Enables Diagnosis. Radiology. 2014;271(3):831-8.

56. Brammerloh $M$, Morawski M, Weigelt I, Reinert $T$, Lange $C$, Pelicon $P$, et al. Measuring the iron content of dopaminergic neurons in substantia nigra with MRI relaxometry. bioRxiv. 2020;1:1-25.

57. Fearnley JM, Lees AJ. Ageing and Parkinson's disease: substantia nigra regional selectivity. Brain. 1991;114(1):2283-301.

58. Takahashi H, Watanabe Y, Tanaka H, Mihara M, Mochizuki H, Takahashi K, et al. Comprehensive MRI quanti fi cation of the substantia nigra pars compacta in Parkinson's disease. Eur J Radiol [Internet]. 2018;109(May):48-56. Available from:

https://doi.org/10.1016/j.ejrad.2018.06.024

59. Ohtsuka C, Sasaki M, Konno K, Kato K, Takahashi J, Yamashita F, et al. Differentiation of earlystage parkinsonisms using neuromelanin-sensitive magnetic resonance imaging. Park Relat Disord [Internet]. 2014;20(7):755-60. Available from: http://dx.doi.org/10.1016/j.parkreldis.2014.04.005

60. Du G, Liu T, Lewis MM, Kong L, Wang Y, Connor J, et al. Quantitative susceptibility mapping of the midbrain in Parkinson's disease. Mov Disord. 2016;31(3):317-24.

61. Chen $\mathrm{Q}$, Chen $\mathrm{Y}$, Zhang $\mathrm{Y}$, Wang $\mathrm{F}$, Yu H, Zhang $\mathrm{C}$, et al. Iron deposition in Parkinson's disease by quantitative susceptibility mapping. BMC Neurosci [Internet]. 2019;20(1):1-8. Available from: https://doi.org/10.1186/s12868-019-0505-9

62. Lotfipour AK, Wharton S, Schwarz ST, Gontu V, Schäfer A, Peters AM, et al. High resolution 
medRxiv preprint doi: https://doi.org/10.1101/2021.04.13.21255416; this version posted April 20, 2021. The copyright holder for this preprint (which was not certified by peer review) is the author/funder, who has granted medRxiv a license to display the preprint in perpetuity.

It is made available under a CC-BY 4.0 International license .

Iron and neuromelanin in PD using 7T MRI - P a g e $\mid 24$

692

693

694

695

696

697

698

699

700

701

702

703

704

705

706

707

708

709

710

711

712

713

714

715

716

717

718

719

720

721

722

723

724

725

726

727

728

729

730

731

732

733

734

735

736

magnetic susceptibility mapping of the substantia nigra in Parkinson's disease. J Magn Reson Imaging. 2012;35(1):48-55.

63. Bergsland N, Zivadinov R, Schweser F, Hagemeier J, Lichter D, Guttuso T. Ventral posterior substantia nigra iron increases over 3 years in Parkinson's disease. Mov Disord. 2019;34(7):1006-13.

64. He N, Ling $H$, Ding B, Huang J, Zhang $\mathrm{Y}$, Zhang Z, et al. Region-specific disturbed iron distribution in early idiopathic Parkinson's disease measured by quantitative susceptibility mapping. Hum Brain Mapp. 2015;36(11):4407-20.

65. Guan X, Xuan M, Gu Q, Huang P, Liu C, Wang N, et al. Regionally progressive accumulation of iron in Parkinson's disease as measured by quantitative susceptibility mapping. NMR Biomed. 2017;30(4).

66. Youdim MBH, Ben-Shachar D, Riederer P. Is Parkinson's disease a progressive siderosis of substantia nigra resulting in iron and melanin induced neurodegeneration? Acta Neurol Scand. 1989;80(1):47-54.

67. Jellinger K, Kienzl E, Rumpelmair G, Riederer P, Stachelberger H, Ben-Shachar D, et al. IronMelanin Complex in Substantia Nigra of Parkinsonian Brains: An X-Ray Microanalysis. J Neurochem. 1992;59(3):1168-71.

68. Kordower JH, Olanow CW, Dodiya HB, Chu Y, Beach TG, Adler CH, et al. Disease duration and the integrity of the nigrostriatal system in Parkinson's disease. Brain. 2013;136(8):2419-31.

69. Greffard S, Verny M, Bonnet AM, Beinis JY, Gallinari C, Meaume S, et al. Motor score of the unified Parkinson disease rating scale as a good predictor of lewy body-associated neuronal loss in the substantia nigra. Arch Neurol. 2006;63(4):584-8.

70. Biondetti E, Gaurav R, Yahia-Cherif L, Mangone G, Pyatigorskaya N, Valabrègue R, et al. Spatiotemporal changes in substantia nigra neuromelanin content in Parkinson's disease. Brain. 2020;143(9):2757-70.

71. Tambasco N, Paolini Paoletti F, Chiappiniello A, Lisetti V, Nigro P, Eusebi P, et al. T2*weighted MRI values correlate with motor and cognitive dysfunction in Parkinson's disease. Neurobiol Aging [Internet]. 2019;80:91-8. Available from: https://doi.org/10.1016/j.neurobiolaging.2019.04.005

72. Zhang W, Sun SG, Jiang YH, Qiao X, Sun X, Wu Y. Determination of brain iron content in patients with Parkinson's disease using magnetic susceptibility imaging. Neurosci Bull. 2009;25(6):353-60.

73. Péran P, Cherubini A, Assogna F, Piras F, Quattrocchi C, Peppe A, et al. Magnetic resonance imaging markers of Parkinson's disease nigrostriatal signature. Brain. 2010;133(11):3423-33.

74. Vaidya M V, Collins CM, Sodickson DK, Brown R, Wiggins GC, Lattanzi R. Dependence of B1+ and B1- Field Patterns of Surface Coils on the Electrical Properties of the Sample and the MR Operating Frequency. Concepts Magn Reson Part B Magn Reson Eng. 2016;46B(1):25-40.

75. Malik SJ, Beqiri A, Padormo F, Hajnal J V. Direct Signal Control of the steady-state response of 3D-FSE sequences. Magn Reson Med. 2015;73(3):951-63.

76. Cassidy CM, Zucca FA, Girgis RR, Baker SC, Weinstein JJ, Sharp ME, et al. Neuromelaninsensitive MRI as a noninvasive proxy measure of dopamine function in the human brain. Proc Natl Acad Sci U S A. 2019;116(11):5108-17.

77. Priovoulos N, van Boxel SCJ, Jacobs HIL, Poser BA, Uludag K, Verhey FRJ, et al. Unraveling the contributions to the neuromelanin-MRI contrast. Brain Struct Funct [Internet]. 2020;225(9):2757-74. Available from: https://doi.org/10.1007/s00429-020-02153-z 
medRxiv preprint doi: https://doi.org/10.1101/2021.04.13.21255416; this version posted April 20, 2021. The copyright holder for this preprint (which was not certified by peer review) is the author/funder, who has granted medRxiv a license to display the preprint in perpetuity.

It is made available under a CC-BY 4.0 International license .

Iron and neuromelanin in PD using 7T MRI - P a g e | 25

737

738

739

740

741

742

743

744

78. Watanabe T, Tan Z, Wang X, Martinez-Hernandez A, Frahm J. Magnetic resonance imaging of noradrenergic neurons. Brain Struct Funct [Internet]. 2019;224(4):1609-25. Available from: http://dx.doi.org/10.1007/s00429-019-01858-0

79. Henkelman RM, Stanisz GJ, Graham SJ. Magnetization transfer in MRI: A review. NMR Biomed. 2001;14(2):57-64.

80. Yarnykh VL. Fast macromolecular proton fraction mapping from a single off-resonance magnetization transfer measurement. Magn Reson Med. 2012;68(1):166-78. 